\title{
Educational Trip With Teeth Doll to Promote Dental Health in Preschool-Age Children
}

\author{
Diah Sulistyowati \\ Faculty of Public Health, Muhammadiyah University of Jakarta \\ K.H. Ahmad Dahlan St, Cireundeu, Ciputat, South Jakarta, Banten 15419 \\ E-mail: diah.s.zainuri@gmail.com
}

\begin{abstract}
The case of children with dental caries in 2017 was found at 79.8 percent and 82.83 percent in 2018 in Public Health Center Cibeber. Preschool-age children visit dental poly in 2018 only 206 children from approximately 1,536 children. Dental caries in a childcause cavities, pain, sleep disorders, and broken teeth, which can cause food absorption disorders that will affect child's growth and development delay, it can decrease child's level of intelligence, so preschool-age children's awareness of the importance of dental and oral health needs to be increased. Innovative dental health promotion by making the health care as a trip vacation, it was an Educational Trip with Teeth Doll or an E-Bogi Trip. To analyze the innovation of E-Bogi Trip as an effort to promote dental health in preschool-age children used qualitative descriptive methods, research in March through December 2019, at Public Health Center Cibeber Cilegon City, uses a purposive sampling with a deep study analysis technique. E-Bogi Trip has matched the characteristics of innovation, having interesting ideas with visual media and teeth doll, has a new idea of health promotion, good planning with the governing support, cross programs, cross sectors and the goals of that innovation can be achieved. Innovation was done well, seen from the increase in preschool-age visits to dental poli in 2019 to 395 children and 569 preschool-age children have an ability on dental care. It's was matched the characteristics of innovation and can increase efforts to promote preschoolage children's dental health, which is expected to achieve good dental health and can develop optimally.
\end{abstract}

Keywords: E-Bogi Trip, Dental Health, Preschool-Age Children. 


\section{INTRODUCTION}

The 2017 Global Burden of Disease Study reported that dental and oral diseases affect nearly 3.5 billion people worldwide, with cases of permanent dental caries being the most common condition. Globally, an estimated 2.3 billion people suffer from permanent dental caries and more than 530 million children suffer from caries on the first-born teeth. ${ }^{(1)}$ Based on The National Report of Basic Health Research (RISKESDAS) 2018 states that 36.6 percent of preschoolers with the age range of 3-4 years in Indonesia have dental caries and only 4.3 percent of children with that age range receive treatment from the dentist. ${ }^{(2)}$

Dental caries is a bacterial infectious disease that damages the lining of the tooth email causing cavities, causing pain, sleep disorders, and broken teeth, if untreated can cause impaired absorption of food that will affect the growth of children, especially in preschoolers. (3) Other impacts caused by dental caries in preschoolers are obstacles to the child's development to lower the level of intelligence of the child and impact on the quality of life of the community. ${ }^{(4)}$

Research on dental health survey on early detection of dental caries prevention in preschoolers by brushing their teeth in Babakan Village, Ciparay Subdistrict, Bandung Regency in 2020 showed that the prevalence of dental caries in toddlers aged (3-5 years) is 81.7 percent, with the prevalence of dental caries according to age is 60 percent at age 3 years, age 4 years is 85 percent, and age 5 years is 86.4 percent, this indicates that the age of toddlers is a vulnerable group of dental caries. ${ }^{(5)}$

Preschool-age children's awareness of the importance of dental and oral health needs to be improved because, with good dental and oral health conditions, the child can grow and develop optimally, the way to increase awareness of preschool-age children is by health counseling by health workers with counseling media that attracts the attention of children so that the child becomes more understanding, willing, and able to maintain dental and oral health. (6)

One of the Public Health Centers located in Cilegon City of Banten Province is Public Health Center Cibeber. ${ }^{(7)}$ Public Health Center through the Health Promotion Program and School Health (UKS), has routinely carried out health screening, periodic health checks, and dental oral checks as well as regular counseling of dental oral health in school children. (8) Health screening in 2017 obtained data that 53.66 percent of elementary/MI students require dental care, who get dental care is 3.1 percent, and cases of children with dental caries is 79.8 percent. (9) While in the health screening and healthy visits of preschool-age children to Dental Poly in 2018, there was 81.62 percent of elementary/MI students requiring dental care, who received 56.3 percent of care, and cases of children with dental caries were found to be 82.83 percent and healthy 
visits of preschool-age children to Dental Poly as many as 206 preschool-age children per year or 13.41 percent. ${ }^{(10)}$ There are still high cases of children with dental caries and low coverage of healthy visits of preschool-age children to Dental Poly, so it is necessary to increase the Promotion of Dental Health of preschool-age children with Educational Trip with Teeth Dolls or known as E-Bogi Trip, which is expected to increase the knowledge of preschool-age children about dental and oral health and reduce children's concerns when visiting Dental Poly.

\section{METHODS}

The type of research used in this study is a qualitative descriptive method. The research was conducted from March to December 2019 at Public Health Center Cibeber Cilegon City. The informants of this research are the Head of Public Health Center and E-Bogi Trip Team including EBogi Trip innovators, namely Dentists who also serve as Representatives of Quality Management, Health Promotion program managers, Nutrition program managers, Environmental Health program managers, and Medical Recorders and other informants, namely kindergarten (TK)/RA/PAUD teachers as many as 15 (fifteen) teachers and 2 (two) parents of preschoolers who participated in EBogi Trip activities in Public Health Center.

The data collection techniques in this study use observation techniques, semi-structured interviews using source triangulation, and documentation to collect data.

Data processing consists of data reduction, data presentation, which then continues towards conclusion or verification, and the data is analyzed with in-depth studies.

\section{RESULTS AND DISCUSSION}

The results of the study were obtained from observations and semi-structured interviews conducted online. Observations were made by researchers during the implementation of E-Bogi Trip activities that took place at Public Health Center Cibeber, while interviews were conducted using the Whatsapp application. The results of the research obtained are as follows :

1. Observation

a. E-bogi trip activities in preschool-age children are held every month on friday at the second and the fourth week, starting at 08.00 wib until the finish of the activity, promotional activities are carried out in the hall of public health center cibeber and simulation of how dental treatment is carried out at the dental poly public health center, the stages of implementation of its activities include :

b. Reception of preschool-age children and teachers from tk/ra/paud by the head of public health center and e-bogi trip team, who had previously registered and had been scheduled to visit public health center, 
c. The backs of children's hands and teachers stamped by e-bogi sign as a mark to enter the mini cinema e-bogi,

d. Introduction of e-bogi trip team, distribution of the property of teeth, vegetables, and fruits to children as well as introductions to teeth doll,

e. Children and teeth doll watching animated films of dental and oral health, handwashing with soap (ctps), fond of eating vegetables, and the contents of my plate, guided by the e-bogi trip team,

f. Teeth doll's show teaches children how to brush their teeth well, as well as invite representatives of preschool-age children who are present to demonstrate how to brush their teeth well so that children understand and can do it independently and time is provided questions and answers,

g. Singing together while learning about maintaining dental health in mini cinema e-bogi, so the children feel happy and interested to learn about dental and oral health, ctps, fond of eating vegetables, and the contents of my plate, so that children understand, want, and able to maintain dental health,

h. After the promotional activities in the public health center hall, a photo was taken together, then the children and teachers were invited to visit the dental poly, and at the end of the activity, the children were given a simulation of how to treat teeth and how to maintain teeth in public health center, so that preschool-age children do not feel worried anymore when having to check themselves to the public health center, its caused dental checks visits and treatments in public health center can increase.

i. Release of preschool-age children and teachers who have finished visiting public health center by e-bogi trip team.

2. Interview

The results of the interview that has been conducted, based on the characteristics of E-Bogi Trip activities as an innovation in the efforts of Dental Health Promotion of preschool-age children and the success or positive impact of E-Bogi Trip activities are as follows :

a) E-Bogi Trip activities have their characteristic

"This E-Bogi Trip activity has a characteristic, the idea was raised because in Public Health Center Cibeber there has been no counseling to preschoolers by using visual media and teeth doll to introduce to children as early as possible about dental health, nutritious food, and dental services. The first idea is the anxiety experienced by innovators, namely dentists who serve also as representatives of quality management because the counseling is only counseling health workers Public Health Center to schools with the delivery of materials only, so less interesting, unique, and memorable for preschoolers so that the health message 
is less remembered by preschoolers. The second idea is because preschool- age children often visit places while studying, such as visits to the Police Department, Department of Firefighter, and other workplaces, so why do preschool-age children did not visit the Public Health Center, because Public Health Center is not only for sick people but also for health promotion, so innovators want preschoolers to know that going to Public Health Center can also be for consultation and routine dental care is not scary as preschoolers think."

The process of turning distinctive or creative ideas into new activities or useful methods of activity is innovation. ${ }^{(11)}$ E-Bogi Trip activity has its characteristic because the idea to provide counseling or dental health education to preschoolers with visual media, singing together, and Teeth Doll aids carried out with a tour visit to Public Health Center is presented more interesting, so that the expected results can be achieved, increasing healthy visits of Dental Poly and can improve health promotion indicators which is counseling groups of preschoolers.

b) E-Bogi Trip activities have a characteristic or element of novelty

"This E-Bogi Trip activity is a new idea of health promotion, E-Bogi activities are packed with fun learning, preschool-age children are given information about dental health in a form that is easily understood by children, such as watching cartoons, watching EBogi's show, singing together so that children can understand health information easily. Educational activities using the property are nothing new, but with Teeth Doll and mini cinemas, especially in Cilegon City is a new idea."

Innovation is a new idea that runs to initiate or seed a product, process, or service. (12)

The novelty element of E- Bogi Trip innovation is the renewal or improvement of the implementation of Health Promotion activities, this activity is carried out nonmonotonously, presented more attractively with visual media and Teeth Doll, more interactive, there is two-way communication, and the opportunity of preschoolers to practice health education that has been provided by the E-Bogi Team.

c) E-Bogi Trip activities are conducted through a planned program

"E-Bogi Trip activities are very well planned, there is cross-program coordination, socialization of activities, and the composition of schedules of activities involving crosssectors. The stages are material collection, maturation of E-Bogi Trip concept, consultation, and requesting support from the Head of Public Health Center, then making KAK (Activity Reference Framework), making SOP (Standard Operational Procedure) E-Bogi Trip Activities, coordination with cross-programs involved, it was Dental Poly, Health Promotion program, Nutrition program, Environmental Health Program, and Medical 
Recorder because there is a simulation of registration until taking medicine, coordination with the school for scheduling and implementation of E-Bogi Trip that is shared in Whatsapp group of TK/RA/PAUD, the excellent response given by the school and parents, activities were held twice a month, then limited to 20 TK/RA/PAUD in 2019, preparation of materials in video and tools such as teeth doll, property of vegetables, songs that will be sung by preschoolers, E- Bogi stamps to enter the mini cinema E-Bogi and prepare the room to be used for the cinema." Planning an activity must be well prepared so that the activities to be carried out can run following expectations, consultation and support from leaders are required, as well as coordination of activities with cross-related and cross-sector programs. For the activities to be sustainable, after planning and implementing activities, balanced with monitoring and evaluation of activities. Activity planning is a well-planned program as evidenced in the E-Bogi Trip activity evaluation report, which starts from the planning, implementation, supervision, and evaluation of activities.

d) E-Bogi Trip activities have goals and directions to be achieved

"The purpose of the activity is to educate preschool-age children to know and apply the knowledge given during E-Bogi Trip, especially about dental health, so that children are not afraid to go to the dentist, the children will diligently brush their teeth, and consume fruit and vegetables, with this innovation increases the coverage of group counseling to preschoolers and helps convey health messages to preschoolers that are packaged uniquely and interestingly. Not only dental health education delivered during the E-Bogi mini cinema, but also CTPS and fondness for eating vegetables, so that preschoolers can maintain their health independently."

Innovation is an important element for the sustainability of an agency or organization because innovation is expected to achieve the desired goal or direction. (14) The goal and direction to be achieved in this activity are to increase the knowledge of preschool-age children about dental health so that preschoolers can maintain their dental health and do not feel worried when having to do dental care in Public Health Center. This activity achieved its goal marked by an increase in healthy visits of preschool-age children who performed dental care at Dental Poly in 2019 as many as 395 children, an increase of about 12.31 percent from the previous year.

e) Successor positive impact on E- Bogi Trip Activities

"In the E-Bogi Trip activity, Public Health Center workers and teeth doll provide knowledge to children in maintaining dental and oral health, handwashing with soap, and enjoy eating vegetables, by singing together, taught also how to take good teeth and mouth 
care and children are allowed to practice it, so that children are more understanding and willing to do it at home, in addition to being exemplified how to treat teeth in Public Health Center, starting from registration and visiting Dental Poly so that children are not afraid to be treated again. The success of the activity is seen from the increasing frequency of group counseling in the building to 96 times, there have been 20 TK/RA/PAUD who visited The Public Health Center to get dental health education, increasing the knowledge of preschool-age children about dental health, so that children are able and willing to maintain dental health, namely as many as 569 children and children do not feel worried anymore when having to do dental care in Public Health Center so that healthy visits of preschoolers to Dental Poli to 395 children in 2019."

Dental and oral health is part of the health service that emphasizes more on counseling activities to minimize the impact of dental caries and achieve the highest level of public health and the achievement of a healthy, caries-free Indonesia by 2030. ${ }^{(15)}$ The success or positive impact of the activity is that as many as 569 children gain knowledge about dental health and understanding about taking good care of teeth, the frequency of group counseling in the building to 96 times, and the increase of healthy visits of preschoolers to Dental Poly to 395 children.

\section{CONCLUSIONS AND SUGGESTIONS}

Educational Trip with Teeth Doll or E-Bogi Trip in preschool-age children in Public Health Center Cibeber has the characteristics of activities as innovations in the efforts of Dental Health Promotion so that this activity can increase the scope of the program because it has its characteristic and novelty elements, namely dental health education using visual media, singing together, using Teeth Doll, the trip to Public Health Center with interesting presentations, interactive, two-way communication, and given the opportunity to preschool-age children to practice health information that has been provided by the E-Bogi Team. This activity is well planned, judging from the initial process stage of the activity and the E-Bogi Trip innovation evaluation report compiled by the E-Bogi Team, This activity has a goal and direction that can be achieved that can be seen from the success or positive impact that there are 569 children gain knowledge about dental health and understand about caring for good teeth and children do not feel worried anymore when having to do dental care in Public Health Center, so that healthy visits of preschool-age children to Dental Poly increased by 12.31 percent to 395 children compared to 2018.

E-Bogi Trip activities to remain consistently carried out by the E-Bogi Trip Team, so that the objectives are achieved and the results of this study are expected to be the material for further research with a similar theme. 


\section{THANK-YOU NOTE}

Thank you to all who have participated in the preparation of this manuscript, especially to the E-Bogi Trip Team at Public Health Center Cibeber Cilegon City.

\section{REFERENCES}

1. WHO. Oral Health. https://www.who.int/news- room/fact-sheets/detail/oral-health.2020;

2. Tim Riset Kesehatan Dasar 2018. Laporan Nasional RISKESDAS 2018 [Internet]. Badan Penelitian dan Pengembangan Kesehatan Kementerian Kesehatan RI. Jakarta; 2019. Available from: http://labdata.litbang.kemkes.go.id/ images/download/laporan/RKD/20 18/Laporan_Nasional_RKD2018_F INAL.pdf

3. Nurman Hidaya MTS. Gambaran Kejadian Karies Gigi Pada Anak Sekolah Dasar. J Chem Inf Model [Internet]. 2018;9(9):11. Available from: https://jurnal.stikes-aisyiyahpalembang.ac.id/index.php/Kep/arti cle/view/114

4. Yuniar N, Putri W. Perspektif Orang Tua pada Kesehatan Gigi Anak Usia Dini. 2019;3(1):161-9.

5. Ardayani T, Zandroto H. Deteksi Dini Pencegahan Karies Gigi Pada Anak dengan Cara Sikat Gigi di Paud Balqis, Asifa dan Tadzkiroh di Desa Babakan Kecamatan Ciparay Kabupaten Bandung. JPKMI (Jurnal Pengabdi Kpd Masy Indones. 2020;1(2):59-67.

6. Harmita AN. Pengaruh Penyuluhan Metode Bernyanyi terhadap Pengetahuan Kesehatan gigi dan mulut anak prasekolah di PAUDINI Cendana Rumbai. Universitas Sriwijaya; 2020.

7. Tim Penyusun Profil Puskesmas. Profil Puskesmas Cibeber 2018. Cilegon; 2018.

8. Kebudayaan KP dan, Kesehatan K, Agama K, Negeri KD. Peraturan Bersama Antara Menteri Pendidikan dan Kebudayaan Republik Indonesia, Menteri Kesehatan Republik Indonesia, Menteri Agama Republik Indonesia, dan Menteri Dalam Negeri Republik Indonesia Nomor6/X/PB/2014, Nomor 73 Tahun 2014, Nomor 41 Tahun 2014,. Jakarta; 2014. p. 1-11.

9. Cilegon DKK. Profil Dinas Kesehatan Kota Cilegon 2018. Cilegon; 2018.

10. Cilegon DKK. Profil Dinas Kesehatan Kota Cilegon 2019. Cilegon; 2019.

11. Robbins SP, Mary C. Management.Tenth edit. Surabaya: Erlangga;2010.21 p.

12. Robbins SP, Judge TA. Organizational behavior.Fourteenth. New Jersey 07458: Pearson education; 2011. 77-89 p.

13. Suprapti W. Bahan Ajar Diklat Kepemimpinan Tingkat III: Agenda Inovasi Budaya Kerja Dalam Efektifitas Kepemimpinan. Jakarta: Lembaga Administrasi Negara Republik Indonesia; $2015.216 \mathrm{p}$.

14. Kristanti MM. Analisis Pengaruh Inovasi Organisasi, Inovasi Strategis, dan Diferensiasi Pasar: Tantangan Keberlanjutan Perbankan Online Indonesia. J Inspirasi Bisnis dan Manaj.2020;4(1):67.

15. Direktorat Bina Upaya Kesehatan Dasar, Ditjen Bina Upaya Kesehatan KK. Indikator Penilaian Keberhasilan Pelaksanaan Pelayanan Kesehatan Gigi dan Mulut. Vol. 5. Jakarta: Kementerian Kesehatan RI; 2015. 